\title{
Decision communication in education management
}

\author{
Ştefan Vlăduţescu*, Claudiu Marian Bunăiașu, Alexandru Constantin Strungă \\ University of Craiova, 13 A. I. Cuza Street, 200585, Craiova, Romania \\ *E-mail address: stefan.vladutescu@yahoo.com
}

\begin{abstract}
In the decision making process in education management, the communicational component has an important role. Communication is the sine qua non factor of the decision. Since it takes place in the decision situation, the type of communication that permeates the processes of making and implementation of managerial decisions was named decision communication.
\end{abstract}

Keywords: decision; education management; communication; decision making; decision communication

\section{INTRODUCTION}

The work of any leader or manager, as well as the specific tasks of the education management process involves decision making. In general, the success or failure of the activity of education management, including management performance depends mostly on the quality and effectiveness of decisions made. They are closely related to the quality of the human factor and the intrinsic quality of human resources (Shackle, 2010; Borowski, 2013; Borowski, 2014).

Decision constitutes a fundamental element of education management. It is the most important tool for the expression of leadership. Management decision causes a multitude of effects, such as direct and indirect effects; natural and perverse effects, effects of risk and opportunity (Chernoff \& Moses, 2012). In some cases, management decisions have immediate consequences in the managed entity, sometimes it generates consequences in an extended time horizon. In human relations in organizational entities, decision has implications not only vertically, but horizontally as well. Therefore, it is necessary the analytical and synthetic study of decision-making. Decision and decision making directly affects the organizational behavior, the quality of management, the organizational climate and human resource results in an organizational entity.

Education management activity forms the core of human resource management. This core includes all the knowledge obtained through scientific methods that are focused on:

- professional activities, conducted by trained, formed persons authorized to implement the management requirements into practice;

- activities of e-learning and training in decision making;

- set of enforcement activities or implementation of decisions into practice;

- engaging mood for progress; 
- specific vision reflected by a certain way of conceiving, seeing, evaluating, searching, and especially accepting decisions and progress.

In the context of these activities which are converging, the management is a set of decisions, actions and activities related to the development of organizational entities. From an operational perspective, the management consists of forecasting, planning, organization, control, guidance, cooperation and development control of the organizational entity. The aim is to ensure the functional maintenance, improvement and transition of a system from one state to another by using a set of tools, processes, methods and rules developed in accordance with the requirements of objective, general or special laws of the management.

\section{COMMUNICATION IN DECISION ACTIVITY}

The management activity involves: charge;

- the relationship between the manager and the staff of the structure that is in his

- the management of the material and time resources he has available;

- the procedural and structural streamlining and optimizing of the organizational entity in relation to the objectives, priorities and available resources;

- maximizing the useful effects by minimizing the resource consumption.

The management of organizational entities is inconceivable without making decisions about their development and decision communication is a form of communication manifested most strongly in the management process (Ehninger \& Brockriede, 2008). The functionality and sustainability of organizational entities, regardless of their nature, will be provided by decision. The success or failure in the management activity and performance of a manager depends largely on the quality and efficiency of decisions, on his decision-making skills of communication.

As part of the management process, decision communication is the process of defining the precise nature of the issues on which decisions are to be made, developing scenarios and variants of solving, solution selection, establishment and communication of the decision, pursuing its fulfillment and its correction by a new management act. Decision is the core of decision making communication and is, finally, the fact that management must intervene in the efficient management of the organizational entity. In this respect, decision is a deliberate process of rational choice of a variant of action to achieve a set objective (Mangra, Stanciu \& Mangra, 2010; Mangra, Cotoc \& Traistaru, 2014).

In the decision-making process, decision communication refers to:

- the decision-making process, as a whole of the stages through which a decision is prepared, analyzed, adopted, implemented and evaluated;

- the decision management act that consists of conveying decision as disposition, task, order etc.

Following the decision made, the management activity engages the staff in charge, encouraging them to understand and accept the decision, and then act in a certain way, for getting the results in due time. The tangible and intangible factors of decision communication are: the decider, the information available, the problem to get solved, the scenarios and possible, probable or imposed alternatives, the objectives achieved and key priorities, the 
specific management, the time resource, the decision, the implementation of the decision, the consequences of the decision.

When these factors are manifested synergistically, we speak of a decision that, depending on the environmental feature, can be of three types:

- decision-making situations of certainty (which are characterized by maximum likelihood to achieve the objective, the elements used are of the controllable variables type whose characteristics are known and whose outcomes could be anticipated with accuracy);

- decision-making situations of uncertainty (they are specific the fact that it is likely to achieve the objective, but the way chosen is relatively weak- based, there are a large number of variables with few control exceptions);

- decision-making situations of risk (situations in which the target is made possible with appreciable probability, but with great uncertainty regarding the procedures, methods, ways to follow, given that there are a large number of uncontrollable variables.

The basic requirements of any decision are:

- a fundamental concept with clearly-defined goals;

- the operation of a management strategy;

- the practical manifestation of the correlation system that makes visible the cohesion between the actionable connections on different plans;

- the responsible conduct of the decision making processes.

The decisions used in human resource management can be classified according to the following criteria:

- the criterion of the decision object, we distinguish: strategic decisions (referring to a period longer than one year, they contribute directly to achieving the fundamental objectives of the organizational entity, they integrate strategies, plans or programs on long or medium term); tactical decisions ( refer to shorter periods, focus on achieving derived objectives, which are integrated into policies and plans with a time horizon shorter than one year); operational or current decisions (objectives contributing to solving individual and microgroup objectives (Traistaru, 2013);

- in relation to the management echelon of development and adoption, there are: upper echelon decisions (strategic and tactical decision), medium echelon decisions (tactical and operational decisions) and base echelon decisions (operational decisions);

- taking into account the frequency they are made, there can be: unique decisions (those decisions that have an exceptional nature, not repeating in the foreseeable future); regular decisions (which are used from time to time, so the use of models and algorithms being possible); random decisions (decisions to be made at irregular intervals and are thus difficult to predict).

The decision is central to a long and complex decision-making process of communication because practically it is just a sequence of this process and consists of an act of authority, compulsory for the coordinated organizational entity (Sandu, Ponea \& Unguru, 2010; Usurelu \& Sandu, 2012). Any decision must be communicated in a clear and workable way to all those responsible for its fulfillment. The transmission and explanation of the decision is within the competence of the manager. For the good implementation of the decision, the manager must have a balanced behavior and play the role of a bridge between the management team and performers. Getting performance largely depends on the existence of an efficient communication system, on the knowledge and judicious use of formal and informal channels, ascending, descending and transverse channels (Voinea, 2011; Sandu, 
Cojocaru, Gavrilovici \& Oprea, 2013; Caras \& Sandu, 2014). First of all, when planning and implementing the decision we must take into account the human resources available, their skills and professionalism. This is because the implementation of such decisions fundamentally depends on both the motivation force of those involved in decision-making and the quality of organizational structures, the state of discipline and responsibility (Vlasa, 2009; Anderson, 2012; Strechie, 2013).

The decision is a communication and action element found at the intersection of several variables:

$$
\mathrm{D}=(\mathrm{C} \times \mathrm{I} \times \mathrm{R} \times \mathrm{F} \times \mathrm{L} \times \mathrm{M} \times \mathrm{CD})
$$

where:

$\mathrm{D}$ is the decision;

$\mathrm{C}$ - the capacity of knowledge;

I - the information held;

$\mathrm{R}$ - the human and material resources available;

$\mathrm{F}$ - the functionality organizational entity;

$\mathrm{L}-$ the legal and regulatory limits;

$M$ - the environment in which the organizational entity operates; its risks and opportunities;

$\mathrm{CD}$ - decisions communication.

Each person directly or indirectly involved in implementing the decision should have that information necessary and sufficient for engaging and completing the decision.

\section{THE BASIC MODEL OF DECISION MAKING}

The research has led to outline a basic model of the development and implementation of the decision (Payne, Bettman \& Johnson, 1993; Kroening \& Strichman, 2008;) . The model is dynamic, which gives guarantee of effectiveness. Following it allows the development of a strategic decision even at the level of the entity, without external intervention, by taking into account and the inferential integration of the involved elements and the mutual relationships between them in a natural logic scheme.

The basic decision model is conducted over six stages:

1. The first step is the identification, assessment and the structural definition of the problem and it is to determine, in time and space, out of the multitude of problems of the organizational entity, those with impact and relevance in the optimal functioning. The defining elements and the place of manifestation of the problem must be specified (Cojocaru, 2005; Sandu, 2009; Negrea, 2010; Calin \& Buniiasu, 2010). Also, it is necessary to clarify the degree of novelty of the problem in order to assess whether, while analyzing, we can use previously encountered cases and the knowledge and the know-how held;

2. The second step is to establish the objective to achieve by the decision made to solve the problem. For this, we will establish whether there is a correlation between the structure of the organizational entity's goals and the objective to be achieved; this objective must fulfill four conditions: they must be understandable, achievable somehow measurable and stimulating (Kirkwood, 1997; Cojocaru, Sandu \& Ponea, 2010; Sandu \& Unguru, 2014);

3. The third step is the establishment of scenarios and decision alternatives/variants about concrete ways of achieving the goals. To sketch the variants we will call on the very 
experience of the staff and of the leadership and the decision alternatives will be subject to the evaluation of the trained ones and the relevant views will be retained (Bunaiasu, 2014);

4. The fourth stage is the analysis and decision making in relation to a set of evaluation criteria. In this context we choose the optimal decision and we make the action plan drawn up by sub- objectives, timelines and practical tasks (Bratu, 2013; Opran, 2014)

5. The fifth step is to implement the decision in accordance with the plan agreed and approved. According to the feedback we proceed to corrections;

6 . The sixth step is to assess the results after implementing the decision. We make a list of the sub- goals met and those unfulfilled.

Any decision taken and implemented will induce a new variable in the organizational entity to which it will respond. This will generate a chain of effects that the manager must notify, assess and understand their impact on the organizational entity (Nicolescu, 2014). We also need to decide whether the effects observed are consistent with the initial decision.

\section{CONCLUSION}

The decision is the essence of the management act. Basically, the decision is a communicative manifestation, with both communication components and analytical and action components. The internal articulation of the decision is a natural logic one reinforced with elements of psychology, sociology, and specialty items specific to the domain in which it manifests. Instead, the articulating procedural and externally applicative articulation is deeply communicative. The decision must be considered in communicational context, it must be debated within the organizational entity, it must be communicatively brought to the attention of the staff, it must be implemented through communication tools and its effects must be managed, checked and controlled with communicative openness. The external articulation of the decision is a communicational one. The decision is part of decision communication. Decision communication can be considered as a way of existence of the management act aiming to solve problems related to the efficient conduct or the development of the organizational entity.

\section{ACKNOWLEDGEMENT}

This paper was co-financed from the European Social Fund, through the Sectorial Operational Programme Human Resources Development 2007-2013, project number POSDRU/159/1.5/S/138907 "Excellence in scientific interdisciplinary research, doctoral and postdoctoral, in the economic, social and medical fields EXCELIS", coordinator The Bucharest University of Economic Studies.

\section{References}

[1] D. R. Anderson (2012). An introduction to management science: Quantitative approaches to decision making. Cengage Learning.

[2] A. Caras, A. Sandu (2014). Epistemic and Pragmatic Backgrounds of Supervision of Ethics. Procedia-Social and Behavioral Sciences, 149, 142-151.

[3] Andrzej Borowski, International Letters of Social and Humanistic Sciences 14 (2014) $33-41$. 
[4] Chernoff, H., \& Moses, L. E. (2012). Elementary decision theory. Courier Dover Publications.

[5] S. Cojocaru, A. Sandu, S. Ponea (2010). Appreciative Evaluation of Training Programs: Case Study: Lumen Consulting and Training Center. Social Research Reports, 8.

[6] Andrzej Borowski, International Letters of Social and Humanistic Sciences 14 (2014) 7-17.

[7] Ştefan Vlăduţescu, American International Journal of Contemporary Research 3(10) (2013).

[8] Ştefan Cojocaru (2005). Metode apreciative în asistența socială: ancheta, supervizarea, studiul de caz. Polirom.

[9] J. H. Gasderell, International Letters of Social and Humanistic Science 22 (2014) 85-91.

[10] Ștefan Vlăduțescu, International Letters of Social and Humanistic Sciences 7 (2014) 8-13.

[11] Max G. Craig, Journal of Studies in Social Sciences 8(1) (2014).

[12] Kroening D., Strichman O. (2008). Decision procedures (Vol. 5). Heidelberg: Springer.

[13] M. G. Mangra, E. A. Cotoc, A. Traistaru (2013). Sustainable Economic Development Through Environmental Management Systems Implementation. Journal.

[14] X. Negrea (2010). Criza economica în presa locala. Gazeta de Sud. Revista de Stiinte Politice, 25.

[15] J. Novak-Marcincin, D. Gîfu, A. Nicolescu (2014). The standard of axes in ontology of communication. International.

[16] F. Smarandache, Ș. Vlăduţescu, A. Nicolescu, (2014). Disinformation as an intentional and legal failure of communication. Current Communication Difficulties, 9.

[17] J. O’Brien (2014). Football, Cultural Identity and Democracy: A Spanish Communication Labyrinth. Topical Communication Uncertainties, 95.

[18] M. Sîrbu, O. Doinea, M. G. Mangra (2009). Knowledge based economy - The basis for insuring a sustainable development. Annals of the University of Petrosani, Economics, 9(4), 227-232.

[19] J. O'Brien (2014). Communicating Football in the context of Spanish society. Current Communication Difficulties, 26.

[20] B. Okwiet, A. Țenescu, A. Nicolescu (2014). Social, communicational and law responsibility in multinational companies. Topical Communication Uncertainties, 149.

[21] S. Ponea, B. Vlasă, Revista Romaneasca pentru Educatie Multidimensionala (2010) 93-98.

[22] A. Sandu (2009). Tehnici afirmativ-apreciative. O sociopedagogie a succesului. Lumen.

[23] A. Nicolescu, Revista de Ştiinţe Politice. Revue des Sciences Politiques (2014).

[24] A. Borowski, International Letters of Social and Humanistic Sciences 3 (2013) 69-74. 
[25] A. Sandu, S. Ponea, E. Unguru, Revista Romaneasca pentru Educatie Multidimensionala 2(5) (2010) 109-130.

[26] M. G. Mangra, M. Stanciu, D. Stuparu (2007). The mandatory pension funds managed by private structures-a viable alternative to the public pension system, the Scientific Bulletin of the Nicolae B lcescu Land Forces Academy, Sibiu, nr. 2/2009 Modern Commercial Assurance, Oeconomica Collection.

[27] A. Sandu, Revista romaneasca pentru educatie multidimensionala - Journal for Multidimensional Education 6(1) (2014) 39-66.

[28] A. Sandu, Postmodern Openings 3 (2014) 49-66.

[29] Maria Măcriş, Iwona Grabara (2014). Production cost in conditions of the global economy-a form of nonverbal communication. Current Communication Difficulties, 194.

[30] F. Smarandache, Ș. Vlăduţescu, A. Nicolescu (2014). Disinformation as an intentional and legal failure of communication. Current Communication Difficulties, 9.

[31] A. Sandu, D. Cojocaru, C. Gavrilovici, L. Oprea, Revista Romana De Bioetica 11(1) (2013).

[32] Antonio Sandu, Elena Unguru (2014). Acțiune comunicativăa, justiție deliberativă și restaurativă. București: Editura Tritonic.

[33] Mihai Coman (2003). Mass-media, mit și ritual. Iași: Editura Polirom.

[34] G. Rajović, J. Bulatović, International Letters of Social and Humanistic Sciences 6 (2013) 24-35.

[35] D. Gifu, M. Kolcun, B. Teodorescu, International Letters of Social and Humanistic Sciences 24 (2014) 66-73.

[36] M. G. Mangra, M. Stanciu, G. I. Mangra, Revista Academiei Fortelor Terestre 15(1) (2010).

[37] A. Borowski, International Letters of Social and Humanistic Sciences 2 (2014) 110-121.

[38] M. G. Mangra, A. R. Daea, M. Stanciu (2009). The Role of European Union in Financing International Development Using Budget Support. Revista tinerilor economişti, (13 special), 15-18.

[39] Joanna Tabor, Journal of Management Studies 9(1) (2014) 233-243.

[40] M. Ştefan, C. Bunăiaşu, A. Strungă (2012). Academic learning-from control and systematic assistance to autonomy. Procedia-Social and Behavioral Sciences, 33, 243-247.

[41] Sebastian Kot, Beata Ślusarczyk (2014). IT Role in Supply Chain Collaboration. Current Communication Difficulties, 165.

[42] D. V. Voinea (2011). Extinderea dreptului de vot la 16 ani-responsabilizarea tinerilor sau incurajarea imaturitaţii. Revista de Stiinte Politice.

[43] Bratu, Elena Rodica (2012). Titlul jurnalistic. Constrângeri și funcții. In Comparatism, identitate, comunicare. Craiova: Editura Universitaria. 
[44] A. C. Strunga, C. M. Bunaiasu, Revista de cercetare şi intervenţie socială 40 (2013) 61-77.

[45] S. Usurelu, A. Sandu, Postmodern Openings 11 (2012) 35-42.

[46] B. Vlasa, Revista romaneasca pentru educatie multidimensionala - Journal for Multidimensional Education 2 (2009) 39-51.

[47] M. Strechie (2008). Oameni politici ai Romei antice: lideri, instituţii şi mentalităţi. Univ.

[48] R. A. Călin, C. Bunăiaşu (2010). Communication and Mass-media-from Information to Formation. Petroleum-Gas University of Ploiesti Bulletin, Educational Sciences Series, 62.

[49] C. M. Bunaiasu, Journal Plus Education 10(2) (2014) 69-76.

[50] X. Negrea, Revista de Stiinte Politice 27 (2010).

[51] A. R. A. Călin (2010). Communication Competences Training for Managers through Role-Play Activities. Annals of University of Craiova-Economic Sciences Series, 3(38).

[52] M. Strechie, International Letters of Social and Humanistic Sciences 7 (2014) 56-61.

[53] Opran, Elena Rodica (2014). The press title as micro-narration. Journal of Romanian Literary Studies, 4, 121-127.

[54] Jason L. Powell, International Letters of Social and Humanistic Sciences 16(2) (2014) 132-143.

[55] Xenia Negrea, Revista de Stiinte Politice 24 (2009).

[56] Mihai Coman (1999). Introducere în sistemul mass-media. Polirom.

[57] Roland Lami, International Letters of Social and Humanistic Sciences 29 (2014) 78-81.

[58] Wessam Al Chibani, International Letters of Social and Humanistic Sciences 30(2) (2014) 192-197.

[59] Bratu, Elena Rodica (2013). Tipologia tilurilor jurnalistice. In Comunicare, identitate, comparatism. Craiova: Editura Universitaria.

[60] Ștefan Vlăduțescu, International Letters of Social and Humanistic Sciences 10 (2014) $100-106$

[61] Jason L. Powell, International Letters of Social and Humanistic Sciences 16(2) (2014) 177-183. 